\title{
A vértranszfúzió-takarékos eljárások alkalmazása a szívsebészetben
}

\author{
Koszta György dr. - Sira Gábor Tihamér dr. - Béczy Krisztina dr. \\ Debreceni Egyetem, Általános Orvostudományi Kar, Aneszteziológiai és Intenzív Terápiás Klinika, Debrecen
}

\begin{abstract}
A vérkészítményekhez való hozzáférés világszerte egyre korlátozottabbá válik. A rendelkezésre álló források észszerú felhasználása emiatt is kiemelt jelentőségü napjaink perioperatív betegellátásában. Az összes vérkészítmény-felhasználás közel fele a cardiovascularis sebészetben történik. A jelen közleményben összefoglaltuk a vérkészítmény-megtakarítás lehetséges módszereit a szívsebészeti betegellátás kapcsán, kiemelve a súlyos perioperatív vérzés kezelésével és megelőzésével kapcsolatos szempontokat.
\end{abstract}

Orv Hetil. 2020; 161(37): 1579-1587.

Kulcsszavak: szívsebészeti vérzésellátási algoritmus, viszkoelasztikus tesztek, PCC, fibrinogénkoncentrátum, vértranszfúzió

\section{Patient Blood Management in cardiac anesthesia}

The accessibility to blood products is increasingly limited worldwide. Approximately half of the blood products is utilized in cardiovascular surgery. The rational use of the available blood products has therefore paramount importance in everyday practice. In the present publication, the possible methods of blood-product sparing in cardiac surgery are summarized. We have emphasized the principles of the treatment and the prevention of severe peri-operative bleeding.

Keywords: cardiac surgical bleeding management, viscoelastic tests, PCC, fibrinogen concentrate, blood-component transfusion

Koszta Gy, Sira GT, Béczy K. [Patient Blood Management in cardiac anesthesia]. Orv Hetil. 2020; 161(37): 15791587.

(Beérkezett: 2020. március 25.; elfogadva: 2020. április 20.)

\section{Rövidítések}

$\mathrm{ACT}=$ (activated clotting time) aktivált alvadási idő; $\mathrm{ADH}=$ antidiuretikus hormon; ANH = akut normovolaemiás haemodilutio; ATIII = antitrombin-III; ATACAS = Aspirin and Tranexamic Acid for Coronary Artery Surgery; CABG = (coronary artery bypass grafting) coronariarevascularisatiós műtét extracorporalis keringésben végezve; CHADS-VASc score = pitvarfibrilláció thromboticus kockázatának becslésére használt pontszám; CI = (confidence interval) konfidenciaintervallum; CPDA = citrát-foszfát-dextróz-adenin-tartalmú alvadásgátló és vértartósító oldat; $\mathrm{CT}=($ clotting time $)$ alvadási idő; DDAVP $=$ dezmopresszin; DOAC = direkt ható oralis antikoaguláns; $\mathrm{ECC}=$ (extracorporeal circulation) extracorporalis keringés; $\mathrm{EF}=$ ejekciós frakció; EXTEM = az extrinszik alvadási mechanizmus vizsgálatára szolgáló viszkoelasztikus, betegágy melletti teszt; FEIBA = factor eight inhibitor bypass activity; FFP = friss fagyasztott plazma; FIBTEM = a fibrinogénszint vizsgálatára szolgáló viszkoelasztikus, betegágy melletti teszt; FVIII = a VIII-as számú alvadási faktor; FIX = a IX-es számú alvadási faktor; FXIII = a XIII-as számú alvadási faktor; FXa = a X-es számú aktivált alvadási faktor; GPIIb/IIIa = glikoprotein IIb/ IIIa; $\mathrm{Hb}=$ hemoglobin; HEPTEM = heparinhatás kimutatására szolgáló viszkoelasztikus, betegágy melletti teszt; INR = (international normalized ratio) nemzetközi normalizált ráta; INTEM = az intrinszik alvadási mechanizmus vizsgálatára szolgáló viszkoelasztikus, betegágy melletti teszt; $\mathrm{LMWH}=\left(\mathrm{low}^{-}\right.$ molecular-weight heparin) kis molekulatömegú heparin; MCF $=($ maximal clot firmness $)$ a viszkoelasztikusteszt-regisztrátum maximális szélessége; $\mathrm{OR}=$ (odds ratio) esélyhányados; $\mathrm{PCC}=$ protrombinkomplex-koncentrátum; POCT $=$ (point-of-care test) betegágy melletti teszt; rFVIIa = a VII-es számú rekombináns aktivált alvadási faktor; ROTEM-tesztek (EXTEM, 
INTEM, FIBTEM, APTEM) = rotációs tromboelasztográfia; $\mathrm{ScvO}_{2}=$ (mixed venous oxygen saturation $)$ a szívbe visszatéró vér oxigénszaturációja; SIRS = (systemic inflammatory response syndrome) szisztémás immunválasz szindróma; tPA = (tissue plasminogen activator) szöveti plazminogénaktivátor; TRICS = Transfusion Requirements in Cardiac Surgery; TXA = tranexámsav; UFH = (unfractionated heparin $)$ frakcionálat lan heparin; VWF = Von Willebrand-faktor

A szívsebészeti betegek közel 50\%-a részesül vörösvérsejt-transzfúzióban az ellátása során. A transzfúzió leggyakoribb oka a krónikus anaemia és a vérvesztés.

A transzfúzió a szívsebészetben is magasabb mortalitási és morbiditási mutatókkal társul. A kedvezőtlen kimenetel valószínűsége a transzfundált vérkészítmények számával párhuzamosan nő. Az anaemia mint kockázati tényező szerepel a mütét utáni alacsony perctérfogat szindróma, az akut veseelégtelenség, a neurológiai károsodások és a halálozás vonatkozásában. Speciális szakterületi szempontként figyelembe kell vennünk azt is, hogy a meglévő vagy bármely okból kialakuló anaemiával öszszefüggő csökkent oxigénszállítási kapacitás kompenzálási lehetôségei a súlyos cardialis alapbetegség miatt eleve beszúkültek.

Az extracorporalis keringési technika miatt a súlyos SIRS kialakulásának valószínűsége magasabb. A transzfúzió potenciális szövődményei szempontjából a szívsebészeti betegek különösen veszélyeztetettek.

\section{A preoperatív anaemia a szívsebészetben}

A szívmütétre kerülő betegek életkora az utóbbi években jelentős mértékben nőtt. Az időskorú betegek körében a vérszegénység 40\%-os gyakorisággal fordul elő. Az anaemia a posztoperatív szövődmények - különösen az akut veseelégtelenség - fellépésének egyik legfontosabb prediktora, és természetesen nagyobb transzfúziós igényt vetít előre.

Szívmütét alatt az extracorporalis keringés időszakában és közvetlenül azt követően jelentős haemodilutio következhet be, és vérzés nélkül is a szöveti oxigenizációt veszélyeztető, alacsony hemoglobinszint állhat elő, ha a kiindulási, preoperatív hemoglobinszint $120 \mathrm{~g} / 1$ alatti, és a beteg vérvolumene alacsony.

Nagyon alacsony hemoglobinszintnél, közvetlenül az ECC után, a helyreállított spontán keringés első óráiban a szöveti oxigénfelvétel ellátásfüggő (supply-dependent) lesz, és transzfúzió nélkül a megfelelő szöveti oxigenizáció nagy valószínüséggel nem lesz fenntartható.

Megfontolandó tehát $120 \mathrm{~g} / 1$ alatti hemoglobinszintû, microcytás anaemiás betegek mütét előtti hematológiai vizsgálata és az anaemia gyógyszeres korrekciója, melynek legegyszerúbb formája a vas, a folsav és a $\mathrm{B}_{12^{-}}$ vitamin pótlása, de a tényleges hemoglobinszint-emelkedéshez hetek szükségesek.
Súlyos anaemia és nem egyértelmúen vashiányos eredet esetén elengedhetetlen a hematológiai konzultáció. Parenteralis vaspótlást akkor tartunk szükségesnek, ha a mútétig rövid idő áll rendelkezésre, vagy felszívódási zavar áll fenn.

$\mathrm{Az}$ eritropoetin elsősorban a nem vashiányos anaemia kezelésére szolgáló készítmény. Szívmütét előtti alkalmazása megfontolandó krónikus vesebetegséggel összefüggő anaemia esetében és akkor, ha a beteg a transzfúziót elutasítja. Hematológiai konzultáció ebben az esetben mindenképpen szükséges [1].

\section{A vérzés kockázatának felmérése}

Szívmütétek kapcsán a vérzés kockázata fokozott, és emiatt a transzfúzió gyakoribb az alábbi tényezők fennállása esetén:

- magas életkor,

- kettős thrombocytagátló kezelés,

- preoperatív anaemia,

- kis testméret,

- nói nem,

- nem elektív mútét,

- komplex mütét,

- ismételt, 'redo' mútét,

- vérzékenységet okozó öröklött vagy szerzett hematológiai alapbetegség.

Ismertek a szívmútét kapcsán jelentkező vérzés menynyiségének és súlyosságának előrejelzésére kidolgozott pontrendszerek, melyek közül a legismertebb a Papworth Bleeding Risk Score [1-3].

\section{A standard laboratóriumi tesztek szerepe a vérzés elörejelzésében}

Általánosan elfogadott perioperatív vérzési rizikófaktor az alacsony $(<1,5 \mathrm{~g} / \mathrm{l})$ fibrinogénszint. Ennek pozitív prediktív értéke azonban csak $20 \%$.

A $100 \mathrm{G} / 1$ alatti thrombocytaszám szintén magas vérzési kockázatot jelez előre, de a tisztázatlan okú thrombocytopenia transzfúzióval történő preoperatív korrekciója elektív szívmütét esetén nem javasolt.

Mind a fibrinogénszint, mind a vérlemezkeszám korrekciójának optimális időpontja rutin 'on-pump' mütét esetén a 'post-bypass' fázis, amikor a heparinhatást már felfüggesztettük. Szívmotor nélküli mütét esetén is a heparin közömbösítéséig várhatunk a thrombocytaszuszpenzió adásával [4].

Speciális eset a 'redo' szívmútét, amikor a 'pre-bypass' fázis jelentősen elhúzódik: ekkor 'cell saver' használata javasolt, és az előrehozott faktor- és thrombocytapótlás egyénileg mérlegelendő.

Kumarinkezelés vagy előrehaladott májbetegség kapcsán INR $<1,5$ esetén már nem kell fokozott vérzési kockázattal számolnunk. 


\section{A POCT-k szerepe a vérzési kockázat felmérésében}

A viszkoelasztikus tesztek szerepe korlátozott. A thrombocytafunkció betegágy melletti (bedside) vizsgálata viszont a thrombocytagátló szerek hatásának kimutatása kapcsán, a mütét időzítése szempontjából bír jelentőséggel.

\section{A thrombocytagátló és véralvadásgátló gyógyszerek preoperatív alkalmazásának szempontjai}

\section{Aszpirin}

A $100 \mathrm{mg} /$ nap dózisban alkalmazott aszpirin csökkenti a perioperatív infarktus és minden ischaemiás esemény kockázatát. Nem szignifikáns mértékben fokozza a vérzés mennyiségét a szívmütét posztoperatív időszakában. A vérzés kockázata 300 mg-os napi dózis felett jelentősen növekszik.

$\mathrm{Az}$ aszpirin szívmưtét előtti elhagyása nem javasolt sem primer, sem szekunder prevenciós indikáció esetén. $\mathrm{Az}$ aszpirint a mütétet követő 48 órán belül visszaadva szignifikáns mortalitáscsökkenést figyeltek meg. Az aszpirin kihagyása 5 nappal a mútét előtt csak abban az esetben fontolandó meg, ha a vérzés következményeinek kockázata igen magas, vagy a transzfúzió kivitelezése valamilyen ok miatt nem lehetséges.

\section{Kettôs thrombocytagátlás}

Kettős thombocytagátló kezelés szükséges, ha a coronaria, stent vagy egyéb artéria thromboticus elzáródásának kockázata igen magas. A kettős thrombocytagátlás a posztoperatív vérzés kockázatát lényegesen megemeli.

Elektív mútét esetén a klopidogrélt 5 nappal, a tikagrelort 3 nappal, a praszugrélt 7 nappal a beavatkozás előtt javasolt kihagyni, míg az aszpirint a mütétet megelőző napig folytatjuk. Azonnali sürgősség esetén biztosítsunk thrombocytaszuszpenziót és egyéb, a felhasználás miatt valószínúleg pótlandó faktorokat. Sürgető mútét, de nem azonnali sürgősség és magas coronariathrombosis-rizikó társulása esetén megfontolandó az áthidaló kezelés GPIIb/IIIa gátló adásával.

\section{A GPIIb/IIIa gátlók}

A GPIIb/IIIa gátlókat fóleg katéterintervenciók kapcsán és áthidaló (bridging) kezelésként használjuk. Az idesorolható szerek: eptifibatid, tirofiban és abciximab. Elhagyásuk után a thrombocytafunkció 24-48 órán belül helyreáll. A tirofiban esetében ez már 2-4 óra alatt bekövetkezik. Ez utóbbi a mútét előtt csak 4 órával hagyandó el.

\section{K-vitamin-antagonisták}

A K-vitamin-antagonisták a thromboemboliás kórképek hosszú távú megelőzésében alkalmazott gyógyszerek. A K-vitamin-antagonisták elhagyását követően az INR 3-5 nap alatt a lényeges vérzési kockázatot már nem jelentő 1,5-ös érték alá csökken.

Ezen időszak alatt a K-vitamin-antagonisták helyettesítése szükséges LMWH-val a következő esetekben:

1. 4 héten belüli pulmonalis embolia,

2. mechanikus múbillentyü,

3. reumásbillentyư-betegséggel társult pitvarfibrilláció,

4. pitvarfibrilláció magas thromboticus kockázattal.

A thromboticus kockázat felmérésére a $\mathrm{CHA}_{2} \mathrm{DS}_{2} \mathrm{VASc}$ score vált széles körben elfogadottá. A magas thromboticus kockázat és a K-vitamin-antagonista elhagyása kapcsán LMWH-profilaxis indítása javasolt, ha a $\mathrm{CHA}_{2} \mathrm{DS}_{2}$ VASc score értéke $>4$.

Sürgős mütét esetén a K-vitamin-antagonisták hatásának felfüggesztésére protrombinkomplex-koncentrátum (PCC) adása javasolt $[5,6]$.

\section{DOAC-kezelés}

Ezen szerek leggyakoribb indikációja a primer vagy szekunder thrombosisprofilaxis pitvarfibrilláció esetén. A DOAC-csoportba sorolt szerek: apixaban, edoxaban, rivaroxaban és dabigatrán.

Eliminációjuk döntően renalis úton történik. A renalis elimináció részesedése az apixaban esetén a legkisebb: 25\%-os. Farmakokinetikájuk normális vesefunkció esetén állandó és kiszámítható. A legutolsó bevétel után 48 órával a hatás szinte teljes megszúnésével számolhatunk. Gyakorlati teendők: a vesefunkció ellenőrzése és az utolsó bevétel időpontjának kiderítése. Beszúlkült vesefunkció esetén a vérzés kockázatának fokozódásával számolhatunk. Szinte mindig találunk eltérést a hagyományos koagulációs tesztekben, de az eltérés mértéke nem arányos a hatás erősségével. Ezekben az esetekben javasolható a laboratóriumi gyógyszerszint-meghatározás és a mütét időpontjának halasztása.

A DOAC-okkal kapcsolatos további gyakorlati problémákat az akut és a sürgető szívmütétek, valamint a DOAC-hatás alatt jelentkező, hagyományos készítményekkel uralhatatlan vérzések jelentik. Mindegyik szer esetén rendelkezésre áll antidotum. A dabigatrán esetén ez az idarucizumab, a többi szer esetén pedig az andexanet-alfa. Az előbbi a dabigatrán ellen elóállított antitest, az andexanet-alfa pedig egy rekombináns és kémiailag módosított FXa, amelynek magas a gyógyszermolekula-megkötő képessége, ezért a természetes FXa mintegy regenerálódik, és ezáltal a hatásuk megszűnik. Nem specifikus antidotumnak tekinthetők a PCC-készítmények és a FEIBA. Ezek alkalmazása (D: 30-50 U/kg) magas vérzési kockázat, illetve manifeszt vérzés esetén megengedhető. FEIBA használatakor a 
trombinképződés olyan mértékben felgyorsulhat, hogy az jelentős klinikai thrombosiskészség-fokozódást jelent $[7,8]$.

\section{A perioperatív vérgyújtés módszerei a szívsebészetben}

\section{Preoperatín autológ vérdonáció}

A preoperatív autológ vérdonáció a jelentős szervezési igénye miatt nem vált a mindennapi gyakorlat részévé, és a különleges esetek megoldására fenntartott módszerek közé soroljuk. Autológ vérdonáció nem jön szóba instabil anginák és szignifikáns aortastenosis esetén, illetve $120 \mathrm{~g} / \mathrm{l}$ alatti hemoglobinszintnél.

\section{Akut normovolaemiás haemodilutio ( $A N H)$}

Az ANH egy autológ vérgyüjtő technika. Ennek során bizonyos mennyiségű teljes vért távolítunk el a keringésből közvetlenül a mútétet megelőzően, és egyidejúleg volumenpótlás történik krisztalloid vagy kolloid oldatokkal. A vért standard CPDA-s zsákba gyüjtjük, amelyet a mútőben tárolunk, és a mútét végső fázisában reinfúzióra kerül. A fenti technika mögött az a feltételezés áll, hogy alacsonyabb hematokrit mellett, vérzés esetén, relatíve kisebb mértékú a sejt- és faktorvesztés. Az ANH fö célcsoportját azok a betegek képezik, akik kevesebb mint $120 \mathrm{~g} / 1$ hemoglobinszinttel kerülnek mütétre. A fenti módon gyüjtött vér jelentős mennyiségü, funkcióképes thrombocytát és a szükséges véralvadási faktorok nagy részét is tartalmazza. Úgy tûnik, hogy az ANH kismértékben csökkenti a transzfúziós igényt is a posztoperatív vérzés mennyiségének csökkentésén keresztül.

A fenti technika módosítása: a teljes heparinizáció után egy puffert nem tartalmazó transzfúziós zsákba történő vérlevétel. Az ilyen módon gyưjtött vért 4 órán belül vissza kell adni.

\section{Sejtmentés, vörösvérsejtmentés, 'cell saver'}

$\mathrm{Az}$ extracorporalis keringés során rutinszerúen alkalmazunk cardiotomiás szívót. A mütéti területről elszívott vér egyszerü mechanikus szűrést követően az ECC rezervoárjába kerül. A cardiotomiás szívó nem alkalmazható a teljes heparinizáció előtt és azt követően. A 'cell saver' technikát tekinthetjük a cardiotomiás szívó alternatívájának vagy annak a 'post-bypass' és posztoperatív időszakra történő kiterjesztésének. A vér centrifugálása, mosása és szürése annak érdekében szükséges, hogy a potenciális veszélyt jelentő szöveti törmelék, alvadék és egyéb, nem sejtes összetevők a reinfúzió előtt eltávolításra kerüljenek.

Az összegyújtött vér automatizált feldolgozása változó mértékben aktiválja a thrombocytákat és az alvadási faktorokat. A mosási folyamattal összefüggő további szö- vődmény a hígulásos coagulopathia, ha a reinfúzióra kerülő vér mennyisége meghaladja az 1000 ml-t. Relatív ellenjavallatok: malignus sejtek potenciális jelenléte a megmentett vérben (például nagyerekbe törő vesedaganat miatt végzett mütétek), infekció a mütéti területen (például endocarditis miatt végzett mútétek).

A sejtmentés csökkenti a transzfúziós igényt az 'offpump' és a komplex 'on-pump' mútétek esetén egyaránt.

A 'cell saver' használata megfontolandó 'redo' mútétek, komplex mútétek, aortadissectio miatt végzett mütétek esetén és akkor, ha transzfúzió bármilyen okból nehezen vagy egyáltalán nem kivitelezhető.

A feldolgozás nélküli drenátum reinfúziója nem javasolt, mert magas a bakteriális kontamináció veszélye, és nagy mennyiségben tartalmazhat a gyulladásos válasz kialakulásában szerepet játszó citokineket - ezért csak bizonyos életveszélyes mértékű vérzések ellátása kapcsán van létjogosultsága.

\section{Vértakarékos sebészi technikák}

- Szívmotor nélküli mütéti technika

- Helyi vérzéscsillapítás fibrintartalmú ragasztóanyagokkal

- FVIII és aprotinin helyi alkalmazása

- Biokompatibilis, heparinbevonatú csókészlet alkalmazása

- A 'prime' volumen redukciója és a minibypass

\section{A heparinizáció}

ECC során a véralvadás gátlására rutinszerűen frakcionálatlan heparint (UFH) alkalmazunk 300-400 NE/kg kezdő dózisban. A heparin hatását rendszerint ACT- (activated clotting time) méréssel monitorozzuk. A heparinhatás nagyfokú egyéni variációt mutat. Függ a rendelkezésre álló antitrombin-III (ATIII) mennyiségétől, a vascularis endothel állapotától és bizonyos plazmafehérjék koncentrációjától. Ez utóbbi jelentôs mértékben csökkentheti a heparin biológiai hozzáférhetőségét. Az ECC akkor biztonságos, ha az ACT 400 s feletti. A heparin aluldozírozása trombinképződéshez vezet, ami az alvadási faktorok elhasználódása révén a posztoperatív időszakban vérzést okozhat. A heparin túldozírozása viszont a heparin 'rebound' miatti vérzés veszélyét fokozza.

Nagy gyakorlati jelentősége van a heparinrezisztencia felismerésének, amikor az ACT az 500 NE/ kg heparindózis ellenére sem emelkedik a kívánatos 400 s fölé. Ennek hátterében számos mechanizmus állhat: az ATIII szintje öröklötten alacsony, hosszan tartó heparinkezelés kapcsán ATIII-elhasználódás, gyulladásos vagy malignus folyamatokkal összefüggésben megnőhet azon plazmafehérjék mennyisége, amelyek a heparin számára alternatív kötőhelyekként szerepelhetnek.

A heparinrezisztencia kezelése ATIII-koncentrátum adását teszi szükségessé. FFP alkalmazása erre a célra 
már nem javasolt. Ha ATIII-koncentrátum került alkalmazásra, fokozódhat a posztoperatív vérzés mennyisége. Ha ezt tapasztaljuk, INTEM/HEPTEM mérés alapján vezetett heparinhatás-felfüggesztés javasolt.

\section{Gyógyszeres vérzésmegelőzés}

\section{$D D A V P$}

A dezmopresszin (DDAVP) az antidiuretikus hormon $(\mathrm{ADH})$ kémiailag módosított analógja. A módosítás révén az alapmolekula lényegében elveszítette vasoconstrictor tulajdonságát, antidiuretikus hatása prolongálódott és gyengébb lett. Fő hatása a $\mathrm{V}_{2} \mathrm{R}$-hez kötődve az endothelsejtekben tárolt VWF és FVIII exocytosisa, a WeibelPalade-testek kiürítése. Hatására növekszik a szöveti plazminogénaktivátor (tPA) szintje is. A fentiektől független hatása a thrombocyták adhéziójának elősegítése a subendothelialis struktúrákhoz.

Metaanalízisek szerint a DDAVP thrombocytafunkciózavar hiányában nem csökkenti lényegesen a perioperatív vérzés mennyiségét és a transzfúzióigényt, de effektivitása aszpirinhatás alatt már klinikailag szignifikáns lehet.

Felmerültek a DDAVP biztonságosságával kapcsolatos aggályok is, de több tanulmány eredménye alapján a thrombosist okozó, statisztikailag szignifikáns hatása nem igazolódott. Specifikus indikáció hiányában rutinszerü alkalmazása a vérvesztés és a transzfúziós igény csökkentése céljából a szívsebészetben jelenleg nem javasolt $[9-11]$.

\section{A fibrinolysis gátlása}

Antifibrinolyticus szerek: aprotinin, epszilon-aminokapronsav és tranexámsav (TXA). A - kallikreingátló aprotinint biztonsági okok miatt kivonták a forgalomból. Az utóbbi két molekula lizinanalóg, amelyek a plazminogén aktív centrumát blokkolják. A TXA tízszer hatékonyabb, mint az aminokapronsav, és felezési ideje is hosszabb. A jelenlegi klinikai gyakorlatban szinte csak a TXA-t használjuk.

A TXA felezési ideje 2-2,5 óra. A szívsebészetben magas dózisokat alkalmazunk: $100 \mathrm{mg} / \mathrm{kg}$-os telítő adagot, amelyet 0,25-4,0 mg/kg/óra fenntartó adag követ. Ebben a dózistartományban mellékhatásként ritkán görcsrohamok léphetnek fel.

A 2017-ben publikált ATACAS-tanulmányban a TXA hatékonyságát placebóval hasonlították össze olyan betegek körében, akik a CABG-mütét előtt aszpirint kaptak. Igazolódott, hogy a TXA csökkenti a posztoperatív vérzés miatti reoperáció kockázatát és az összes vérkészítményre vonatkozó transzfúziós igényt. Ugyanakkor nem emelkedett a thromboticus szövődmények és az erre visszavezethető halálozás kockázata. A görcsroham fellépésének gyakorisága a TXA-t kapó betegek körében 0,7\%-nak adódott. Egyértelmúen igazolt effektivitása és biztonságossága miatt a TXA rutinszerú alkalmazását javasoljuk [12].

\section{A szívsebészeti vérzés kezelése}

A szívműtét után kialakuló vérzés jelentős mortalitási és morbiditási rizikófaktor. A későn észlelt vagy nem megfelelő hatékonysággal ellátott vérzés következményei rövid és hosszú távon is súlyosak. Elengedhetetlen a drenátum mennyiségének szoros észlelése és az állandó resternotomiás készenlét. Javasolt helyi ellátási protokollok létrehozása és azok beillesztése a minőségbiztosítási rendszerbe. Ennek fö összetevőit az alábbiakban foglaljuk össze.

\section{A potenciálisan vérzést okozó eltérések kontrollja}

A hypothermia gyakori a posztoperatív időszakban. A hypothermiás körülmények között képződött alvadék instabil, $16{ }^{\circ} \mathrm{C}$ alatt az alvadási faktorok szinte teljes mértékben inaktiválódnak. Alacsony testhőmérséklet esetén csökken a thrombocyták adhéziója és aktivációja is.

Mély metabolikus acidózis többnyire jelentős szöveti hypoperfusio miatt lép fel a szívműtött betegeknél. Súlyos acidosis alakulhat ki masszív transzfúzió kapcsán is, mivel a legtöbb vérkészítmény pH-ja 6,0-7,0 közötti. Citráttartalmuk csökkentheti az ionizált Ca-szintet.

Mivel a viszonylag nagy méretû́ vörösvérsejtek az érpályában való áramlásuk során a kisebb méretű és tömegü alvadási faktorokat és thrombocytákat az érfal közelébe kényszerítik, $70 \mathrm{~g} / 1$ hemoglobinszint alatt a primer és szekunder haemostasis múködésének effektivitása romlik.

Az utóbbi években vált ismertté, hogy a kolloid oldatok nemcsak jelentős haemodilutiót okozhatnak, hanem a fibrinpolimerizáció folyamatával is interferálhatnak. A fentiek miatt tanácsos a hidroxi-etil-keményítő-oldatok alkalmazását kerülni, a zselatinoldatokat pedig a lehető legkisebb mennyiségben adni [1, 2, 13-15].

\section{A POCT-k használata a posztoperatín vérzés ellátásában}

Weber és mtsai [16] a 2012-ben megjelent tanulmányukban 50-50 beteget randomizáltak „POCT” vagy „hagyományos vérzésmenedzsment” csoportokba. A POCT-csoportban ROTEM- és Multiplate-vizsgálatok eredményei alapján hoztak terápiás döntést a szívmütétet követő vérzés kezelését illetően. A tanulmányt - a POCT-csoportban észlelt kedvezőbb kimenetel alapján - a tervezettnél korábban befejezték. Weber és mtsai tanulmányukban igazolták az alábbiakat:

1. A POCT-csoportban kevesebb volt - a teljes posztoperatív időszakra vonatkozóan - a vérzés mennyisége. 
2. A POCT-csoportban kevesebb vörösvérsejt, thrombocyta és FFP transzfúziós igény jelentkezett.

3. A POCT-csoportban alacsonyabb PCC- és fibrinogénkoncentrátum-dózisokkal értek el hatékonyabb vérzéscsillapítást. A POCT-csoportban ugyanakkor ritkábban és kevesebb rFVIIa-ra volt szükség.

4. A POCT-csoportban rövidebb volt a lélegeztetési idő, és kedvezóbben alakultak a $\mathrm{PaO}_{2} / \mathrm{FiO}_{2}$ arányok.

5. A POCT-csoportban rövidebb volt a kórházi tartózkodási idő.

6. A POCT-csoportban kedvezőbben alakult a 6 hónapon belüli mortalitás.

7. A POCT alapján végzett vérzésmenedzsment költsége a klasszikus kezeléshez képest közel 50\%-kal kisebb volt.

A fentiek alapján a POCT-kre alapozott vérzésmenedzsment a szívsebészeti aneszteziológiai és intenzív ellátás fontos alapmódszerének tekinthető, és széles körben történő alkalmazása javasolható [16, 17].

A POCT-kre alapozott vérzésellátás lépéseit az 1 . ábrán tekintjük át.

\section{A vérzésellátás faktorkészitményekkel}

\section{Protrombinkomplex-koncentrátum}

'Poolozott', vírusmentesített, humán plazmából állítják elő. Európában szinte kizárólag a 4 faktoros PCC-készítmények állnak rendelkezésre, amelyek a FII., FVII., FIX., FX. alvadási faktorokat tartalmazzák. Ezenkívül az egyes eltérő készítmények tartalmazhatnak még különböző mennyiségű protein-C-t és protein-S-t, ATIII-at és heparint is.

A kumarinhatás felfüggesztése során a szükséges FIXmennyiség az INR alapján jól kidolgozott: 2-3,9 INR között $25 \mathrm{IU} / \mathrm{kg}, 4-5,9$ INR között $50 \mathrm{IU} / \mathrm{kg}, 5,9$ feletti INR esetén $50 \mathrm{IU} / \mathrm{kg}$, szükség esetén INR-kontroll után ismételve. A viszkoelasztikus tesztek eredménye alapján történő adagolása még nincs általánosan elfogadott módon kidolgozva, ilyenkor a CT- és a CTF-értékek megnyúlását vesszük figyelembe [9].

\section{Rekombináns aktivált FVII}

A rFVIIa-t eredetileg a gátlótestes haemophilia kezelésére fejlesztették ki, de hatékonysága miatt hamar elterjedt 'off-label' (indikáción túli) alkalmazása az egyes sebészi szakterületeken. A rFVIIa alkalmazása akkor javasolt, ha egyéb módon nem sikerül a vérzés csillapítását megoldani. Profilaktikus alkalmazása nem javasolt, mivel kismértékben ugyan, de fokozza a thromboticus események gyakoriságát. A rFVIIa alkalmazása a metaanalízisek szerint nem csökkenti a transzfúziós igényt, de csökkenti a vérzéssel kapcsolatos mortalitást [9].

\section{Fibrinogén}

A fibrinogén a májban termelődő, kb. 340 Da súlyú glikoprotein. A keringésben inaktív formában 1,5-4,0 g/1 koncentrációban van jelen, felezési ideje hozzávetőlege- sen 100 óra. A trombin hatására bekövetkező fibrinogén-fibrin átalakulás a koagulációs folyamat központi lépése. Az így keletkező szolúbilis fibrinmonomerek a FXIII jelenlétében keresztkötődnek, ami vizes közegben oldhatatlan, stabil fibrinhálót eredményez. A fibrinháló a keletkező alvadék stabilitásának fő meghatározó tényezője. A fibrin az aktivált thrombocytákat is keresztköti, és egyéb alvadási tényezők közötti interakció megteremtője, s mint a trombin természetes gátlója (antitrombinI), a koagulációs folyamat egyik inhibitora is.

A rendelkezésre álló fibrinogén teljes mennyisége a vérben kering. Vérvesztés kapcsán a fibrinogén azon faktorok egyike, amelyek koncentrációja a legkorábban csökken. A kritikusnak tartott $1 \mathrm{~g} / \mathrm{l}$-es koncentrációt részleges - alvadási faktorokat nem tartalmazó - volumenpótlást feltételezve kb. 140\%-os vérvesztés esetén érjük el.

Súlyos májcirrhosisban a glikozilációs lépés hibásan megy végbe, emiatt csökkent funkciójú fibrinogén keletkezik (szerzett dysfibrinogenaemia). A fibrinogén laboratóriumi mérése makromolekuláris oldatok (például hidroxi-etil-keményítő, dextrán) használata esetén fals magas értéket adhat. A funkcionális fibrinogénszintre következtethetünk viszkoelasztikus tesztek (FIBTEMMCF) eredményei alapján.

FIBTEM alapján: $2 \mathrm{~g}$ fibrinogén emeli $70 \mathrm{~kg}$-os beteg esetén $4 \mathrm{~mm}$-rel a FIBTEM-MCF értéket. A minimálisan elfogadható FIBTEM-MCF érték $12 \mathrm{~mm}$, de magas vérzési kockázat - például aorta ascendens mútétek kapcsán a 22 mm-es MCF tekinthető optimálisnak. Metaanalízisek eredményei szerint $14 \mathrm{~mm}$ feletti FIBTEM-MCF-nél a vérzés és a transzfúziós igény már nem csökken tovább, feltételezve, hogy nem áll fenn sebészi okú, lumenes vérzés. A standard laboratóriumi tesztek alapján végezve a fibrinogénszubsztitúciót, 30$60 \mathrm{mg} / \mathrm{kg}$ fibrinogén emeli egy $70 \mathrm{~kg}$-os egyén esetén $1 \mathrm{~g} / \mathrm{l}$ értékkel a fibrinogénszintet [18-21].

\section{XIII-as faktor}

A FXIII egy transzglutamináz enzim; ebből a szempontból különleges, mert a legtöbb alvadási faktor szerinproteináz, amelyek általában a fehérjék hasítását végzik. Aktiválódásához trombin vagy magas Ca-koncentráció szükséges. A FXIII fó funkciója a fibrinmonomerek kovalens keresztkötése, amely vizes közegben oldhatatlan, stabil fibrinhálót eredményez. A FXIII felelős azért is, hogy a fibrinmonomerekhez a fibrinolysis inhibitorai is stabilan, kovalensen kötődjenek (például alfa-2-plazmininhibitor). Szerzett FXIII-hiány a leggyakrabban vérzés kapcsán, konszumpció miatt alakul ki. Ez előfordulhat még akut leukaemia esetén, nagy felszínú sebek, például égés kapcsán is. Gyulladásos bélbetegségekben (Crohnbetegség, colitis ulcerosa) is kialakulhat FXIII-hiány. Autoantitestek képződése a FXIII ellen extrém ritka.

Az igen ritka (1/1 millió lakos) congenitalis hiány esetén a klinikai vérzékenység súlyos, heterozigóta formában a vérzékenység jóval enyhébb, de sérülések vagy 


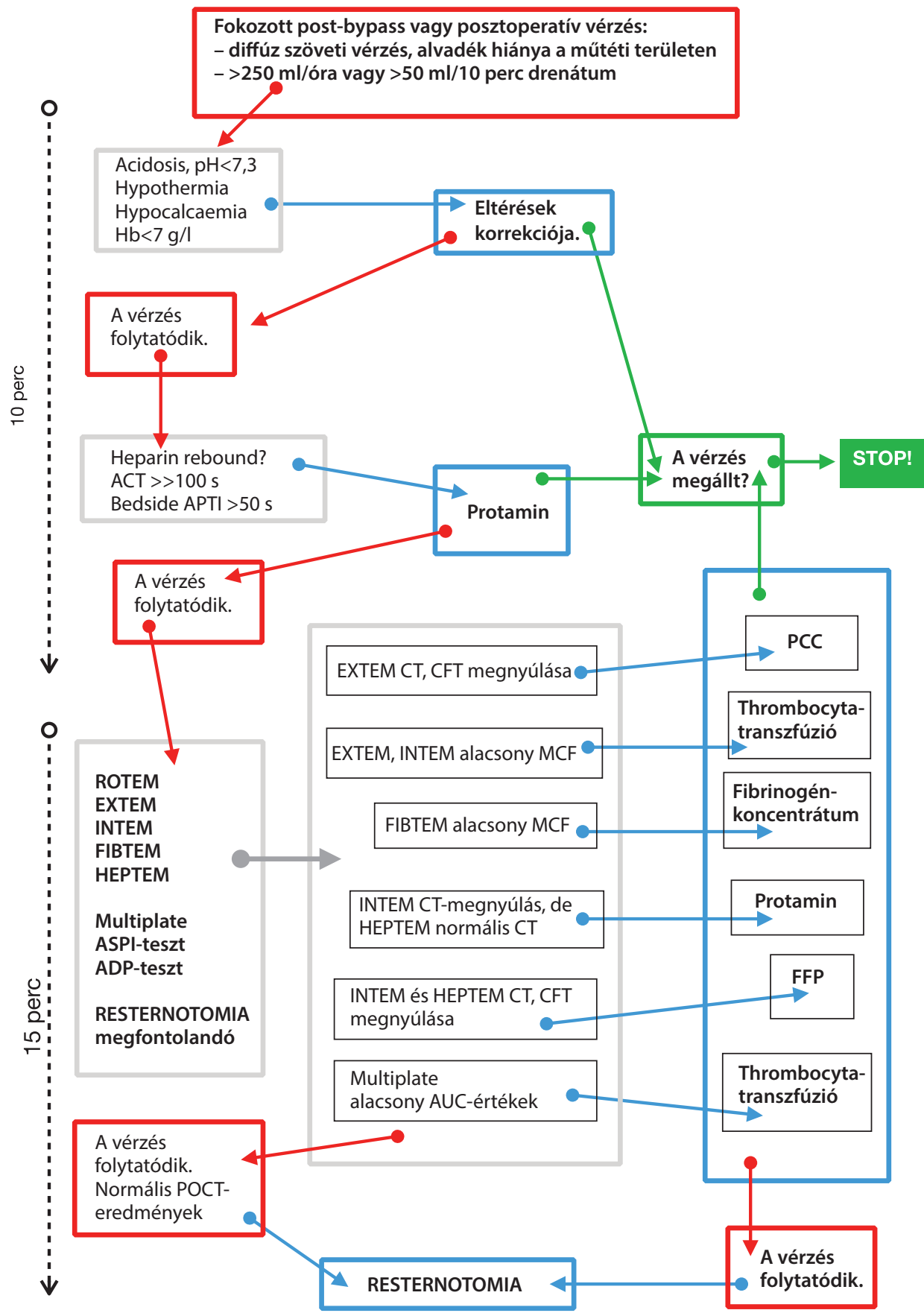

\begin{tabular}{l|l} 
l. ábra & Diagnosztikus és terápiás algoritmus a 'post-bypass’ vérzések esetén extracorporalis szívmútétek során
\end{tabular}

ACT = aktivált alvadási idő; ADP-teszt = adenozin-difoszfát hatására bekövetkező thrombocytaaggregációt mérő, betegágy melletti teszt; APTI = aktivált parciális tromboplasztinidő; ASPI-teszt = arachidonsav hatására bekövetkező thrombocytaaggregációt mérő, betegágy melletti teszt; AUC = görbe alatti terület; $\mathrm{CFT}=$ a vérrögképződés ideje; $\mathrm{CT}=$ alvadási idő; EXTEM = az extrinszik alvadási mechanizmus vizsgálatára szolgáló viszkoelasztikus, betegágy melletti teszt; FFP = friss fagyasztott plazma; FIBTEM = a fibrinogénszint vizsgálatára szolgáló viszkoelasztikus, betegágy melletti teszt; $\mathrm{Hb}=$ hemoglobin; HEPTEM = heparinhatás kimutatására szolgáló viszkoelasztikus, betegágy melletti teszt; INTEM = az intrinszik alvadási mechanizmus vizsgálatára szolgáló viszkoelasztikus, betegágy melletti teszt; $\mathrm{MCF}$ = a viszkoelasztikusteszt-regisztrátum maximális szélessége; PCC = protrombinkomplex-koncentrátum; POCT = betegágy melletti teszt

nagy mütétek során klinikai jelentőségüvé válhat. A szívsebészetben a FXIII-pótlás alkalmazása ritkán szükséges, de gondolnunk kell rá elhúzódó, refrakter vérzések esetén.

A faktorkészítményekre alapozott szívsebészeti vérzés ellátásának algoritmusa az 1 ábrán látható.

\section{Transzfúziós stratégia a szívsebészetben}

A megszorító és megengedő transzfúziós stratégiát öszszehasonlító szívsebészeti, multicentrikus, randomizált tanulmányok és metaanalízisek között az egyik legnagyobb a 2017-ben megjelent TRICS III study, amelybe 
több mint 5000 beteget vontak be. A restriktív csoportban a transzfúziós triggert 7,5 g/dl értékben határozták meg, míg a liberális csoportban ez $8,5 \mathrm{~g} / \mathrm{dl}$ volt, azzal a kitétellel, hogy megengedték az intraoperatív időszakban a 9,5 g/dl értéket is. A tanulmány elsődleges végpontjai: bármilyen okból bekövetkező halálozás, myocardialis infarctus, stroke, dialízist igénylő, új keletű akut veseelégtelenség. Az elsődleges végpont a restriktív csoportban $11,4 \%$-os gyakorisággal fordult elő, míg a liberális csoportban ez 12,5\% volt; OR: 0,9 (95\% CI: 0,761,07). Az eredmények alapján a megszorító transzfúziós stratégia nem bizonyult alsóbbrendűnek a megengedővel szemben.

Nem sikerült igazolni a restriktív stratégia előnyét a magas életkorú (>75 év) betegek körében, beszúkült vesefunkció esetén, azon betegeknél, akiknél izolált coronariamütét történt, és ha a balkamra-funkció nagyon rossz volt $(\mathrm{EF}<20 \%)$. Ezen esetekben az oxigénszállító kapacitás kompenzálásának lehetőségei korlátozottak és a célszervi károsodás veszélye eredendően magasabb volt. Az eredmények megerôsítik azon álláspontunkat, hogy pusztán a hemoglobinszintre alapozott traszfúziós trigger alkalmazása a gyakorlatban nem célravezető [22$25]$.

\section{Fiziológiai hátterü transzfúziós trigger alkalmazása}

A transzfúzió célja az oxigénszállítási kapacitás optimalizálása. A szöveti oxigénellátást a perctérfogat, a hemoglobinkoncentráció, a rendelkezésre álló hemoglobin oxigénszaturációja határozza meg. Normálkörülmények között a szövetek a rendelkezésre álló oxigénnek csak a 25\%-át használják fel. Ha a szöveti oxigénellátás beszúkül, az egyik lehetséges kompenzációs mechanizmus a szöveti oxigénextrakció fokozása. Ilyenkor a szívbe viszszatérő vér oxigénszaturációja $\left(\mathrm{ScvO}_{2}\right) 75 \%$ alá csökken. A szövetek oxigénextrakciója azonban nem fokozódhat az artériás vérben rendelkezésre álló oxigénmennyiség 100\%-áig. A kompenzáció másik módja a perctérfogat emelkedése, amelynek szintén megvannak a fiziológiás korlátai.

Ha a kevert vénás vér oxigénszaturációja és az ezzel jól korreláló centrális vénás szaturáció 75\% alatti, és csökkenő tendenciát mutat, annak a jele, hogy ezen kompenzációs mechanizmusok kimerülőben vannak. Ezt a jelenséget gyakran kíséri szimpatikus tónusfokozódás, intolerábilis szintű tachycardia. Gyakori a vér laktátszintjének emelkedése, ami az anaerob anyagcsere-folyamatok térnyerésével függ össze.

A fenti paraméterek monitorozása segítséget nyújthat abban, hogy a pusztán Hb-szintre alapozott transzfúziós triggert az adott kórélettani szituációnak megfelelően egyénre szabjuk.

\section{Következtetés}

A Patient Blood Management (Hazai adaptációja a Nemzeti Véradó és Vérmentő Program) alapelveinek megvalósítása a szívsebészetben több, egymással komplex módon összefüggo" - közleményünkben ismertetett lépés állandó kontrollját igényli, melynek elsödleges célja a vértranszfúzió gyakoriságának csökkentése. Ez azonban nem lehet öncélú, minden esetben tekintettel kell lennünk a csökkent szöveti oxigenizáció miatti potenciális károsodások veszélyére. Az egyik betegnél megspórolt vér egy másik életét mentheti meg.

Anyagi támogatás: A közlemény megírása anyagi támogatásban nem részesült.

Szerzői munkamegosztás: A szerzők egyenlő mértékben vettek részt a kézirat elkészítésében. A cikk végleges változatát valamennyi szerző elolvasta és jóváhagyta.

Érdekeltségek: A szerzőknek nincsenek a kézirat elkészítésével kapcsolatban pénzügyi vagy egyéb személyes érdekeltségeik.

\section{Irodalom}

[1] The Task Force on Patient Blood Management for Adult Cardiac Surgery of the European Association for Cardio-Thoracic Surgery (EACTS) and the European Association of Cardiothoracic Anaesthesiology (EACTA), Boer C, Meesters MI, Milojevic M, et al. 2017 EACTS/EACTA Guidelines on patient blood management for adult cardiac surgery. J Cardiothorac Vasc Anesth. 2018; 32: 88-120.

[2] Kozek-Langenecker SA, Ahmed AB, Afshari A, et al. Management of severe perioperative bleeding: guidelines from the European Society of Anaesthesiology: first update 2016. Eur J Anaesthesiol. 2017; 34: 332-395.

[3] Vuylsteke A, Pagel C, Gerrard C, et al. The Papworth Bleeding Risk Score: a stratification scheme for identifying cardiac surgery patients at risk of excessive early postoperative bleeding. Eur J Cardiothorac Surg. 2011; 39: 924-930.

[4] Gielen C, Dekkers O, Stijnen T, et al. The effects of pre- and postoperative fibrinogen levels on blood loss after cardiac surgery: a systematic review and meta-analysis. Interact Cardiovasc Thorac Surg. 2014; 18: 292-298.

[5] Shariff N, Aleem A, Singh M, et al. AF and venous thromboembolism - pathophysiology, risk assessment and CHADS-VASc score. J Atr Fibrillation 2012; 5: 649.

[6] Ghadimi K, Levy JH, Welsby IJ. Perioperative management of the bleeding patient. Br J Anaest. 2016; 117(Suppl 3): iiil8iii30.

[7] Hassan K, Bayer N, Schlingloff F, et al. Bleeding complications after use of novel oral anticoagulants in patients undergoing cardiac surgery. Ann Thorac Surg. 2018; 105: 702-708.

[8] Sousa-Uva M, Head SJ, Milojevic M, et al. 2017 EACTS Guidelines on perioperative medication in adult cardiac surgery. Eur J Cardiothorac Surg. 2018; 53: 5-33.

[9] Mahdy AM, Webster NR. Perioperative systemic haemostatic agents. Br J Anaesth. 2004; 93: 842-858. 
[10] Crescenzi G, Landoni G, Biondi-Zoccai G, et al. Desmopressin reduces transfusion needs after surgery: a meta-analysis of randomized clinical trials. Anesthesiology 2008; 109: 1063-1076.

[11] Desborough MJ, Oakland KA, Landoni G, et al. Desmopressin for treatment of platelet dysfunction and reversal of antiplatelet agents: a systematic review and meta-analysis of randomised controlled trials. J Thromb Haemost. 2017; 15: 263-272.

[12] Myles PS, Smith JA, Forbes A, et al. Tranexamic acid in patients undergoing coronary-artery surgery. N Engl J Med. 2017; 376: 136-148. [Correction: N Engl J Med. 2018; 378: 782.]

[13] Skhirtladze K, Base EM, Lassnigg A, et al. Comparison of the effects of albumin 5\%, hydroxyethyl starch $130 / 0.46 \%$, and Ringer's lactate on blood loss and coagulation after cardiac surgery. Br J Anaesth. 2014; 112: 255-264.

[14] Schramko A, Suojaranta-Ylinen R, Kuitunen A, et al. Hydroxyethylstarch and gelatin solutions impair blood coagulation after cardiac surgery: a prospective randomized trial. Br J Anaesth. 2010; 104: 691-697.

[15] Rasmussen KC, Secher NH, Pedersen T. Effect of perioperative crystalloid or colloid fluid therapy on hemorrhage, coagulation competence, and outcome: A systematic review and stratified meta-analysis. Medicine (Baltimore) 2016; 95: e4498.

[16] Weber CF, Görlinger K, Meininger D, et al. Point-of-care testing: a prospective, randomized clinical trial of efficacy in coagulopathic cardiac surgery patients. Anesthesiology 2012; 117: 531-547.

[17] Lier H, Vorweg M, Hanke A, et al. Thromboelastometry guided therapy of severe bleeding. Essener Runde algorithm. Hamostaseologie 2013; 33: 51-61.

[18] Fominskiy E, Nepomniashchikh VA, Lomivorotov VV, et al. Efficacy and safety of fibrinogen concentrate in surgical patients: a meta-analysis of randomized controlled trials. J Cardiothorac Vasc Anesth. 2016; 30: 1196-1204.

[19] Ranucci M, Jeppsson A, Baryshnikova E. Pre-operative fibrinogen supplementation in cardiac surgery patients: an evaluation of different trigger values. Acta Anaesthesiol Scand. 2015; 59: 427433.

[20] Li JY, Gong J, Zhu F, et al. Fibrinogen concentrate in cardiovascular surgery: a meta-analysis of randomized controlled trials. Anesth Analg. 2018; 127: 612-621.

[21] Wikkelsø A, Lunde J, Johansen M, et al. Fibrinogen concentrate in bleeding patients. Cochrane Database Syst Rev. 2013; 2013: CD008864.

[22] Hajjar LA, Vincent JL, Galas FR, et al. Transfusion requirements after cardiac surgery: the TRACS randomized controlled trial. JAMA 2010; 304: 1559-1567.

[23] Murphy GJ, Pike K, Rogers CA, et al. Liberal or restrictive transfusion after cardiac surgery. N Engl J Med. 2015; 372: 9971008. [Correction: N Engl J Med. 2015; 372: 2274.]

[24] Reeves BC, Pike K, Rogers CA, et al. A multicentre randomised controlled trial of transfusion indication threshold reduction on transfusion rates, morbidity and health-care resource use following cardiac surgery (TITRe2). Health Technol Assess. 2016; 20: $1-260$.

[25] Mazer CD, Whitlock RP, Fergusson DA, et al. Restrictive or liberal red-cell transfusion for cardiac surgery. N Engl J Med. 2017; 377: 2133-2144.
(Koszta György dr., Debrecen, Móricz Zs. krt. 22., 4032 e-mail: kosztagy@gmail.com)

Az Orvosi Hetilap 2020, 161, 1308. oldalán (31. szám) megjelent OH-Kvízre három helyes megfejtés érkezett.

\author{
A beküldő: Dr. Bíró László (Budapest), Dr. Kónya Csaba (Budapest) \\ és Dr. Somogyi Erzsébet (Budapest). \\ A nyerteseknek szívböl gratulálunk. \\ Nyereményüket - egy, az Akadémiai Kiadó webáruházában \\ kedvezményes vásárlásra jogosító kupont - e-mailen küldjük el.
}

A cikk a Creative Commons Attribution 4.0 International License (https://creativecommons.org/licenses/by/4.0/) feltételei szerint publikált Open Access közlemény, melynek szellemében a cikk bármilyen médiumban szabadon felhasználható, megosztható és újraközölhető, feltéve, hogy az eredeti szerző és a közlés helye, illetve a CC License linkje és az esetlegesen végrehajtott módosítások feltüntetésre kerülnek. (SID_1) 